Viso - Cadernos de estética aplicada Revista eletrônica de estética

ISSN 1981-4062

No 23, jul-dez/2018

http://www.revistaviso.com.br/

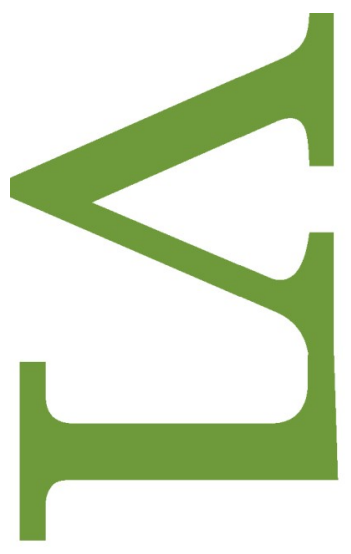

\title{
A poesia filosófica de Hölderlin entre $o$ antigo e o moderno Ulisses Vaccari
}




\section{RESUMO}

\section{A poesia filosófica de Hölderlin entre o antigo e o moderno}

O texto procura mostrar algumas relações possiveis entre filosofia e poesia em Hölderlin, enfatizando o modo como o poeta desenvolve uma linguagem poético-filosófica, necessária como forma de educação ou formação do poeta moderno. Ao mesmo tempo em que pressupõe uma aproximação entre poesia e filosofia, essa linguagem aponta para a superação da filosofia moderna de caráter iluminista, centrada apenas nas funções lógicas do entendimento. Tal superação aparece em Hölderlin como condição necessária para o retorno do poeta como educador da humanidade, à maneira de Homero.

Palavras-chave: poesia - filosofia - educação poética - filosofia da história

\section{ABSTRACT}

\section{Hölderlin's Philosophical Poetry between the Ancient and the Modern}

The text seeks to show some possible relations between philosophy and poetry in Hölderlin, emphasizing how the poet develops a poetic-philosophical language, necessary as a form of education or formation of the modern poet. At the same time it presupposes an approximation between poetry and philosophy, this language points to the overcoming of the enlightened character of modern philosophy, centered only on the logical functions of the understanding. This overcoming appears in Hölderlin as a necessary condition for the return of the poet as educator of humanity, in the manner of Homer.

Keywords: poetry - philosophy - poetic education - philosophy of history 


\section{VACCARI, U. "A poesia filosófica de Hölderlin entre o antigo e o moderno". In: Viso: Cadernos de estética aplicada, v. XII, n. 23 (jul-dez/2018), pp. 105-123.}

\section{DOI: 10.22409/1981-4062/v23i/255}

Aprovado: 17.09.2018. Publicado: 27.12.2018.

(C) 2018 Ulisses Vaccari. Esse documento é distribuído nos termos da licença Creative Commons Atribuição-NãoComercial 4.0 Internacional (CC-BY-NC), que permite, exceto para fins comerciais, copiar e redistribuir o material em qualquer formato ou meio, bem como remixá-lo, transformá-lo ou criar a partir dele, desde que seja dado o devido crédito e indicada a licença sob a qual ele foi originalmente publicado.

Licença: http://creativecommons.org/licenses/by-nc/4.0/deed.pt_BR

Accepted: 17.09.2018. Published: 27.12.2018.

(C) 2018 Ulisses Vaccari. This document is distributed under the terms of a Creative Commons Attribution-NonCommercial 4.0 International license (CC-BY-NC) which allows, except for commercial purposes, to copy and redistribute the material in any medium or format and to remix, transform, and build upon the material, provided the original work is properly cited and states its license.

License: http://creativecommons.org/licenses/by-nc/4.0/ 
...que todos os lugares sagrados da terra se encontrem reunidos em um único lugar e a luz da filosofia entrando pela minha janela: eis o que constitui agora minha alegria

(carta a Casimir Böhlendorff, de 2 de dezembro de 1802)

\section{Introdução}

É relativamente recente o reconhecimento de Friedrich Hölderlin como um dos maiores poetas alemães de todos os tempos. Ignorada ao longo do século XIX, sua poesia veio à tona apenas no início do século XX, mais precisamente em 1913, quando Norbert von Hellingrath reuniu e publicou sua lírica tardia numa primeira edição crítica. Esse esforço pioneiro, tornado um marco na história da recepção de Hölderlin ${ }^{1}$, propagou sua poesia nos meios intelectuais da Alemanha e de outros países da Europa, tornando-o célebre pelas elegias Pão e vinho [Brot und Wein], A festa da paz [Friedensfeier] e Patmos², por exemplo. Essa lírica tardia, curiosamente, despertou o interesse sobretudo dos filósofos do início do século XX, que constituíram seus primeiros leitores críticos e intérpretes.

Em 1905, Wilhelm Dilthey já havia publicado o estudo $A$ vivência e a poesia ${ }^{3}$, situando Hölderlin ao lado de nomes tais como Lessing, Goethe e Novalis. Mas após a empreitada de Hellingrath, a senda de interpretações filosóficas da poesia de Hölderlin, aberta por Dilthey, ganhou continuidade com os estudos de Walter Benjamin, de 1914, "Dois poemas de Friedrich Hölderlin"4, de Ernst Cassirer, em 1918, "Hölderlin e o idealismo alemão", e, na década de 1930, com os "Esclarecimentos sobre a poesia de Hölderlin", de Martin Heidegger. ${ }^{6}$ Essa primeira fase de interpretações filosóficas da poesia de Hölderlin chega até a década de 1960, com o ensaio "Parataxe: Sobre a lírica tardia de Hölderlin", de Theodor Adorno, década em que outro aspecto da produção do poeta, igualmente ignorado até então, alcança a luz do dia, justificando o grande interesse de filósofos por sua poesia. Em 1961, Friedrich Beissner, envolvido com a publicação da Stuttgarter Ausgabe, as primeiras obras completas do poeta, publicou um fragmento filosófico fundamental de Hölderlin, intitulado Juízo e ser [Urtheil und Seyn]. ${ }^{8}$ Este fragmento, quando lido com outros do mesmo período, mostrou que, para além da poesia, Hölderlin esteve profundamente envolvido com os principais temas filosóficos e estéticos de sua época, num rico e intenso diálogo com as filosofias de Kant, Fichte, Schelling e Hegel.

Escrito no frontispício e no verso de uma página arrancada de um livro - que muitos creem se tratar da contracapa da Fundação a toda doutrina da ciência, de Fichte -, Juízo e ser constitui um esboço de uma filosofia, talvez de um sistema filosófico próprio, voltado para a estética, mas que, por motivos nunca esclarecidos, não se consumou como tal. Apesar disso, o fragmento é suficiente para constatar a força e a originalidade do pensamento filosófico de Hölderlin que, conforme se deseja mostrar aqui, anda de par com sua produção poética. Em Hölderlin, poesia e filosofia estão intimamente ligadas numa relação orgânica, o que torna impossível separar uma da outra sem ferir a essência de uma e outra. Por um lado, sua poesia é filosófica, no sentido de que trata 
poeticamente das principais questões da filosofia pós-kantiana (e o que explica o interesse de filósofos por ela); por outro, suas reflexões filosóficas buscam constantemente uma aproximação expositiva da linguagem poética, seguindo o ideal próprio daquele momento de constituição de um filósofo-poeta ou de um poeta filosófico.

\section{Filosofia e poesia}

Os fragmentos propriamente filosóficos de Hölderlin, incluindo Juízo e ser, foram escritos entre 1793 e 1804. Embora seu contato com a filosofia tenha se iniciado no Instituto de Tübingen, entre 1788 e 1793, é a partir de 1794 que a filosofia passa a constituir seu principal interesse, ano em que, instalado em Waltershausen, o poeta começa a estudar a filosofia de Fichte. Em 1795, decide mudar-se para lena ${ }^{9}$, com o propósito de frequentar os cursos sobre a Doutrina da ciência e, nessa cidade, estabelece contato pessoal também com Schiller, a quem sempre admirou e que, a partir desse momento, passa a ser uma espécie de mentor intelectual do jovem poeta. Neste ambiente, escreve alguns dos fragmentos filosóficos mais importantes de sua produção, tais como Juízo e ser, $A$ lei da liberdade e $O$ conceito de punição, textos que perfazem o núcleo de sua nunca realizada filosofia. Nesse mesmo período, escreve o Fragmento de Hipérion, primeira versão, ainda teórica, do seu romance Hipérion ou o eremita na Grécia, concluído e publicado em 1798. A redação concomitante dos fragmentos filosóficos e do romance evidencia a unidade poético-filosófica que desponta em Hölderlin desde a juventude, o que justifica a necessidade, por parte do leitor, de interpretar os fragmentos filosóficos à luz de sua produção poético-literária e vice-versa. O romance Hipérion, a tragédia inacabada $A$ morte de Empédocles e a lírica tardia fornecem um sentido extra para os fragmentos filosóficos, em si mesmos elípticos e reticentes, bem como estes iluminam aqueles, do ponto de vista da teoria.

A aparente falta de sistematicidade, ocasionada pelo estilo fragmentário dos textos de Hölderlin, pode ser assim superada pelo movimento de mão dupla dos esboços filosóficos à poesia e desta àqueles. Por meio da ação recíproca entre ambos os aspectos de sua produção o leitor é capaz de costurar a unidade subjacente a seus fragmentos, acompanhando o movimento propriamente hölderliniano de pensar o poético por meio da filosofia, bem como de tornar a filosofia um pensamento poético.

A profundidade dessa relação entre filosofia e poesia nos textos estéticos de Hölderlin pode ser medida na leitura conjunta dos chamados fragmentos gregos, O ponto de vista a partir do qual devemos enxergar a antiguidade, Sobre Aquiles I e II e Uma palavra sobre a llíada, com o romance Hipérion; ou na leitura dos fragmentos sobre tragédia, $O$ significado das tragédias, o Sobre o trágico e O devir no perecer, entre outros, à luz da própria tragédia $A$ morte de Empédocles. Do mesmo modo, os chamados fragmentos poetológicos, A diferença dos modos poéticos, Os diferentes modos de poetizar, Alternância de tons e Sobre as partes do poema são iluminados e iluminam os poemas 
dos tempos de Homburg (a partir do final de 1799), tais como Wie wenn am Feiertag (Como em dia santo) ou mesmo a ode Dichterberuf (Coragem de poeta), na qual se vê ao mesmo tempo o esforço de superação do subjetivismo e de conquista de uma poesia objetiva, calcada no abandono da métrica cara à ode e na mistura dos gêneros poéticos clássicos (lírico, épico e dramático), cara à forma elegíaca. ${ }^{10}$

Longe de constituir mero diletantismo ou espécie de aventura passageira no percurso intelectual do poeta, a filosofia é uma atividade necessária ao poeta moderno de um modo geral, a forma mais apropriada de tomar consciência de seu métier e de sua tarefa [Aufgabe] de poeta em tempos modernos. Por meio da filosofia, o poeta se conscientiza da perda do papel formador da poesia ao longo da história, bem como de sua tarefa no sentido de reconquistar sua função educadora da cultura, à imagem do modelo homérico de poesia. O pano de fundo dos textos de Hölderlin é perpassado pela necessidade de uma formação [Bildung] poético-filosófica do poeta moderno, que the ensine a grandiosidade e a importância de Homero para a formação da polis grega, por um lado e, por outro, Ihe proporcione a consciência de sua própria função formadora diante da humanidade moderna. Tanto os textos teóricos de Hölderlin, bem como grande parte de seus poemas, tais como Profissão de poeta e Coragem de poeta, o romance e a tragédia sobre Empédocles, nesse mesmo sentido, são destinados não ao grande público, mas ao próprio poeta. Trata-se da constituição de um discurso poético-filosófico cuja finalidade consiste em despertar no poeta a consciência de sua vocação [Bestimmung] de poeta. Eis o contexto do famoso verso da elegia Pão e vinho: "E para quê poetas em tempos de indigência?"11, elegia que traz em si um ensinamento poético destinado a poetas, segundo o qual sua tarefa de um modo geral consiste na preparação e na criação de uma linguagem capaz de cantar o retorno do divino, fugido e afastado da presença humana desde o início do cristianismo: "Porque ele [o poeta] permanece e traz o sinal dos deuses fugidos/Cá pra baixo aos sem-deuses no meio das trevas". ${ }^{12}$

Embora essa criação de uma linguagem poética necessite da aproximação com a filosofia, ela pressupõe ao mesmo tempo a superação da filosofia, entendida em sua acepção moderna, como uma forma de pensamento centrada exclusivamente no intelecto e no entendimento. A limitação da filosofia à atividade intelectual torna ineficaz todo esforço de superação das cisões modernas entre sujeito e objeto, liberdade e necessidade, razão e sentimento, humano e divino, pois a totalidade ou a unidade procurada do Ser só é possível por meio da atuação do todo das faculdades do sujeito. Eis o que difere o homem moderno do grego antigo, no qual o intelecto gozava de uma relação imediata e harmônica com a natureza e a sensibilidade, harmonia presente na sua relação com o divino, própria da poesia homérica. Ao enxergar o mundo apenas por meio do entendimento filosofante, o homem moderno ressente-se da perda da presença da divindade e da relação harmônica com a natureza. Em vez de aproximar o homem da natureza, as filosofias modernas, centradas numa atividade abstrata de pensar, acabaram por acentuar o fosso entre ambos. Nuclear nas filosofias iluministas, o entendimento afinal se define por sua analiticidade, por sua função de separação e 
catalogação do Ser em conceitos e categorias abstratas, que espelha em última instância a visão fragmentada do homem burguês do século XVIII, o homem de negócios. Nas palavras de Schiller: "o espírito de negócio, fechado num círculo uniforme de objetos e, neste, enclausurado ainda mais pelas fórmulas, tinha de perder o todo e empobrecer juntamente com sua esfera". Afinal, quando "o mero intelecto" e "a mera razão" se tornam "os reis do norte"13, "o predomínio da faculdade analítica rouba necessariamente a força e o fogo à fantasia". ${ }^{14}$

Tornar o poeta novamente mestre da humanidade, à maneira de Homero, exige assim um esforço de reconquista do todo, abandonado e esquecido por uma sociedade e uma cultura demasiadamente analíticas. Tornar a poesia a educadora da humanidade significa reconquistar a força e o fogo da fantasia, relegados ao segundo plano em tempos de confiança exagerada no entendimento burguês tabelar. Ecoando a filosofia pós-kantiana como um todo, Hölderlin assume para si esse papel de crítico da sociedade do entendimento e da reflexão ao mostrar, seja nos fragmentos filosóficos, seja em sua obra poético-literária, a necessidade de superação desse momento histórico determinado, o que, nos termos da história da filosofia, equivale à superação do Iluminismo. O Hipérion, por exemplo, traz muitas passagens que apontam nesse sentido, como as que seguem: "É nessas alturas que me encontro com frequência, meu Belarmino! Um momento de reflexão, porém, me joga para baixo"; "o homem quando sonha é um deus, mas quando reflete é um mendigo" "15; "[...] do mero intelecto jamais surgiu algo inteligível e da mera razão jamais surgiu algo razoável". ${ }^{16}$

A proposta de superação do lluminismo pressupõe por sua vez uma filosofia da história, pensada poeticamente no Hipérion e no Empédocles e filosoficamente em alguns fragmentos, especialmente em $O$ devir no perecer. Cíclica em sua essência, essa concepção filosófica da história é subdividida em três estágios: no primeiro, que equivale à postura grega harmônica em relação à natureza, a vida se apresenta em sua naturalidade e simplicidade, numa acepção próxima à do conceito de poeta ingênuo de Schiller; por meio de uma ação do impulso formador [Bildungstrieb], essa vida simples cinde-se em opostos, formando um segundo estágio intermediário, propiciador da reflexão e da filosofia, caracterizado por tentativas sucessivas de recuperar aquela unidade original por meio da abstração conceitual. O terceiro estágio, apenas possível, aponta para o esforço [Streben] de superação do segundo estágio marcado pelo entendimento, apontando para a razão, a faculdade das Ideias e do Ideal. Transposta numa forma filosófico-esquemática, essa tríade, mais uma vez nas palavras de Schiller, soa do seguinte modo: "A natureza (o sentido) unifica sempre, o entendimento separa sempre; a razão, contudo reunifica; por isso, antes de começar a filosofar, o homem está mais próximo da verdade que o filósofo que ainda não terminou sua investigação". ${ }^{17}$ Ao utilizar esse esquema para pensar a história da modernidade, é possível concluir com Schiller e Hölderlin que a Alemanha do final do século XVIII situa-se precisamente na transição do momento da cisão (filosofia) para o da sua superação na razão, a faculdade das Ideias e do Ideal (totalidade). Essa reunificação, no fundo, não deixa de ser um 
retorno ao início, mediado pela razão, tal como se lê na seguinte passagem do Hipérion, que retoma à sua maneira o esquema proposto por Schiller:

É também minha esperança, meu prazer nas horas solitárias que tais sons grandiosos e
outros ainda mais grandiosos tenham de retornar um dia à sinfonia do devir do mundo.
[... Os povos surgiram outrora da harmonia infantil; a harmonia dos espíritos será o
começo de uma nova história do mundo. Os homens tiveram início na felicidade das
plantas, e cresceram, cresceram até amadurecer; a partir daí fermentaram sem cessar,
por dentro e por fora, até a espécie humana ficar infinitamente dissolvida, como um
caos, de modo que a vertigem acometerá a todos que ainda sentem e veem. Mas a
beleza fugiu da vida dos homens subindo em direção ao espírito. Ideal se torna o que foi
natureza quando da árvore ressequida por baixo e desgastada vai surgindo uma copa
fresca, verdejando ao brilho do sol, como outrora o tronco nos dias de juventude. Ideal é
o que foi natureza. Nisso, nesse ideal, nessa divindade rejuvenescida, alguns poucos se
reconhecem e são uma unidade, pois o uno existe neles, e destes, destes começa a
segunda idade do mundo. ${ }^{18}$

A segunda idade do mundo, marcada pela "divindade rejuvenescida" no Ideal, nasce da realização dos três estágios descritos anteriormente: o da felicidade das plantas, o de sua dissolução, que conduz a humanidade ao caos e, por fim, o do retorno da simplicidade da natureza por meio da Ideia e do Ideal. Tal como estipulados por Kant, a Ideia e o Ideal apontam para a totalidade que, possuindo um uso apenas regulativo, não pode ser reduzida e conhecida teoricamente. ${ }^{19}$ Toda tentativa de conhecer teoricamente a Ideia, segundo Kant, caracteriza-se como ilusão transcendental. A filosofia de Kant, com efeito, interdita toda forma de intuição intelectual, que pressupõe dogmaticamente uma relação imediata do sujeito com as formas suprassensíveis, as Ideias. Essa interdição, entretanto, é apenas teórica, pois, no parágrafo 49 da Crítica da faculdade do Juízo, Kant menciona as Ideias estéticas como uma "contrapartida [Pendant] da razão"20, apontando para o fato de que, embora não possam ser teoricamente expostas para fins epistemológicos, as Ideias da razão, contendo em si a totalidade perdida, o Ser propriamente dito, são contemplados em uma exposição [Darstellung] estética, que se realiza por meio da poesia. Não se trata, evidentemente, de um conhecimento teórico do Ser, mas de uma apresentação estética dele (por analogia), tal como se pode ver nas metáforas e imagens poéticas fornecidas por tantos poetas ao longo da história. Embora não se possa conhecer científica e teoricamente o Inferno, o Purgatório e o Paraíso, a Divina comédia de Dante, por exemplo, aproxima-se poeticamente desses conceitos, em si mesmos inefáveis e teoricamente irredutíveis:

O poeta ousa tornar sensíveis ideias racionais de entes invisíveis, o reino dos bemaventurados, o reino do inferno, a eternidade, a criação, etc.; ou também aquilo que na verdade encontra exemplos na experiência, por exemplo, a morte, a inveja e todos os vícios, do mesmo modo o amor, a glória, etc., transcendendo as barreiras da experiência, mediante uma faculdade da imaginação que procura competir com o jogo da razão no alcance de um máximo, ele procura tornar sensível numa completude para a qual não se encontra nenhum exemplo na natureza; e é propriamente na poesia que a faculdade de ideias estéticas pode mostrar-se na sua inteira medida. ${ }^{21}$ 
Hölderlin havia estudado a fundo a Crítica da faculdade do Juízo de Kant, conforme revelam suas cartas do ano de 1794. Numa carta de 10 de outubro de 1794 a seu amigo Neuffer, menciona o estudo concomitante do Fedro de Platão e da parte estética da filosofia kantiana, mas aponta para a necessidade de ir além da teoria das ideias estéticas kantianas ${ }^{22}$, algo que o próprio Schiller, embora tenha chegado perto, não fizera. Apesar de ser difícil estabelecer exatamente o significado desse "passo para além do limite kantiano", é possível interpretá-lo no sentido mencionado acima, no interior de seu projeto de superação da filosofia do lluminismo. Na medida em que se propõe a uma teoria do gosto e se mantém no interior de uma filosofia transcendental, a estética de Kant permanece de algum modo atrelada ao domínio do entendimento. A própria exposição da filosofia kantiana mostra seu comprometimento com o século analítico, de divisão da razão em faculdades, funções e forças, em busca do seu mapeamento completo. O movimento de superação da filosofia do entendimento, encabeçado por Schiller e por Hölderlin, por meio da aproximação com o poético, passa ao mesmo tempo pela transformação da própria linguagem utilizada para a exposição das ideias filosóficas. Em outros termos, o procedimento das ideias estéticas descrito por Kant na Crítica da faculdade do Juízo não explica apenas o modo como o poeta cria suas imagens estéticas, mas aponta também para o procedimento do próprio filósofo em seu trabalho de exposição de suas ideias filosóficas. Tal como consta no texto programático do idealismo alemão, atribuído por muitos ao próprio Hölderlin, também o filósofo deve proceder esteticamente em seu trabalho de exposição:

O filósofo deve possuir tanta força estética como o poeta. Os homens sem sentido estético são nossos filósofos da letra [Buchstabenphilosophen]. A filosofia do espírito é uma filosofia estética. Não se pode ser espirituoso em nada, não se pode sequer pensar espirituosamente sobre história sem sentido estético. ${ }^{23}$

A linguagem a ser utilizada pelo filósofo dotado de sentido estético é distinta da linguagem do entendimento que, ao lidar com conceitos analíticos, apenas aprofunda a fragmentação que visa solucionar. O projeto de superação da filosofia do lluminismo e de criação de uma poética moderna, nesse sentido, inclui a criação de uma nova linguagem filosófica, capaz de apreender e expor o universal não em sua qualidade abstrata, como fez a lógica ao longo da história, mas levando em conta ao mesmo tempo a singularidade e a particularidade do objeto, isto é, considerando também o conteúdo do pensamento e não apenas a sua forma. Para além do mero princípio de identidade ${ }^{24}$, para além do âmbito humano e finito, tal linguagem deve absorver em si também a contradição, o paradoxo, o desconhecido e o monstruoso [Ungeheure], enfim, o divino em toda a sua incompreensibilidade e intangibilidade. Urge a necessidade de criação de uma linguagem capaz de abranger o elemento paradoxal e dialético, uma linguagem na qual a determinação da parte leve sempre em consideração o todo e vice-versa, tal como atestava Schiller nas Cartas: "É somente pela parte que chegamos ao todo, somente pelos limites que chegamos ao ilimitado; por outro lado, é somente pelo todo que chegamos à parte, somente pelo ilimitado chegamos ao limite". ${ }^{25}$ 
Ao contrário de Schiller, no entanto, que procura definir a linguagem dialética, na Carta XIX, teoricamente, como já o havia feito também Fichte na Doutrina da ciência, para Hölderlin o gênero trágico constitui um meio privilegiado de exposição [Darstellung] dessa linguagem dialética. A exposição trágica também visa chegar à determinação do ilimitado pelo limite e vice-versa, mas poeticamente, e não por meio de uma linguagem teórico-intelectual. A tragédia, tal como se pode ver em Édipo e em Antígona, conduz a cisão entre parte e todo a seu limite máximo, fazendo uso da concepção de que apenas na separação ilimitada a parte se torna novamente capaz de unificar-se intimamente com o todo. Fiel ao esboço do Juízo e ser, de 1795, Hölderlin, nas Observações sobre Édipo e Antígona, de 1804, continua a pensar a transposição de uma exposição filosóficodialética em outra de caráter estético, em que a dinâmica da cisão como forma de alcançar a intimidade [Innigkeit] do Ser apareça nos conformes ao projeto de uma filosofia estética:

A exposição do trágico repousa principalmente no fato de que o elemento monstruoso o modo como o deus e o homem se acasalam e como, ilimitadamente, o poder da natureza e o mais íntimo do homem se unificam na ira -, se concebe em virtude do fato de que a unificação ilimitada se purifica por meio da separação ilimitada. ${ }^{26}$

A tragédia, em última instância, transpõe poeticamente a dialética da determinação recíproca segundo a qual a íntima ligação com o Ser só é possível pela separação na ira. ${ }^{27}$ Quanto mais afastados entre si, mais próximos da reconciliação encontram-se os opostos: "Perto está, / E difícil de prender, o Deus. / Mas onde há perigo, cresce / também o que salva", canta no hino Patmos. ${ }^{28} \mathrm{O}$ paradoxo, com efeito, constitui a marca característica de um pensamento todo ele atravessado pela oposição moderna entre homem e deus, como atesta o fragmento $O$ significado das tragédias:

O significado das tragédias pode ser mais facilmente compreendido a partir do paradoxo. Pois tudo o que é original, sendo todo poder justa e igualmente partilhado, não aparece na verdade em sua força originária, mas propriamente em sua fraqueza, de modo que a luz da vida e a aparição pertencem propriamente à fraqueza de cada todo. ${ }^{29}$

Ao poeta moderno cabe cantar o retorno dos deuses fugidos, tema central também da poesia lírica, que, nesse ponto, vê diluída a fronteira em relação ao gênero trágico. Em Pão e vinho, o grande tema é a cisão trágica entre o humano e o divino, cuja superação deve ser cantada pelo poeta: "Mas, amigo! Viemos tarde demais. De-certo vivem os deuses, / Mas lá em cima, noutro mundo, por sobre as nossas cabeças. / Infindamente ali agem e pouco parece importar-lhes / Se nós vivemos ou não, tanto os Divinos nos poupam". ${ }^{30}$ Esse retorno, entretanto, não é um retorno de fato, como se fosse possível reinstaurar como tal a cultura grega, mas um retorno por meio da ausência, à maneira moderna. Na Modernidade, como se lê em O significado das tragédias, o Ser não se apresenta positivamente em sua força originária, mas em sua fraqueza, do mesmo modo que, em Kant, o sublime traz em si uma negatividade intrínseca, originando-se do aniquilamento da sensibilidade, de modo que o ilimitado se origine da determinação do 
limite. Assim como o sublime em Kant só pode ser alcançado negativamente, também o Ser de Hölderlin - a divindade fugida - só se torna efetivamente presente em sua ausência, motivo pelo qual, em sua exposição, seu signo sensível deve aparecer não em sua força original, mas em sua fraqueza: "Se a natureza se expõe propriamente em seu dom mais fraco, então o signo, quando ela se apresenta em seu dom mais forte, será = 0 .". 31

Fiel a Kant, Hölderlin, assim, não pretende um retorno dogmático ao Ser, como se fosse possível apresentá-lo teoricamente por meio do conceito ou de uma intuição intelectual à maneira dos filósofos racionalistas. Ao salientar a natureza irredutivelmente negativa do Ser, Hölderlin mantém conservada sua característica idealista, no sentido de algo em si mesmo e enquanto tal inalcançável. Na esteira de Kant, Fichte e Schiller, Hölderlin também se refere ao Ser como uma tarefa moral, a ser poeticamente realizada, a partir de um ideal cuja aproximação é infinita, o que o situa mais perto do romantismo do que do idealismo absoluto de cunho schellinguiano e hegeliano:

Busco desenvolver a ideia de um progresso infinito da filosofia e mostrar que a exigência que se deve invariavelmente impor, inexoravelmente, a todo sistema de reunir sujeito e objeto num eu absoluto, ou como se queira chamar, só é possível, esteticamente, na intuição intelectual. ${ }^{32}$

Para tornar possível a aproximação infinita da filosofia em relação a um ideal inalcançável, o filósofo deve possuir sentido estético, estreitando as relações e dirimindo os limites rígidos entre filosofia e poesia. Na medida em que se aproxima infinitamente de um ideal em si mesmo inalcançável, os limites, não apenas entre os gêneros lírico, épico e dramático, mas também os limites entre filosofia e poesia se relativizam, e desaparecem. ${ }^{33} \mathrm{O}$ ideal a ser buscado infinitamente, assim, constitui a reabsorção completa da filosofia pela poesia, entendida historicamente como sua origem, a fonte mesma da qual proveio, projeto que Hölderlin procurava desenvolver a partir das Cartas sobre a educação estética de Schiller:

Para tanto [desenvolver a ideia de um progresso infinito da filosofia], necessitamos de sentido estético e pretendo chamar as minhas cartas filosóficas de 'Novas cartas sobre a educação estética do homem'. Pretendo, pois, igualmente, partir da filosofia para chegar à poesia e à religião. ${ }^{34}$

As Novas cartas sobre a educação estética do homem de Hölderlin não se consumaram finalmente, ao menos não com este título. O projeto, em todo caso, foi levado a cabo em conformidade com as exigências filosóficas de Hölderlin, a saber, de uma exposição poética de princípios filosóficos, no Hipérion. O romance, com efeito, é escrito em forma de cartas de seu personagem homônimo a seu amigo Belarmino, nas quais conta sobre sua trajetória ao longo de sua formação como poeta. O chamado romance de formação [Bildungsroman] descreve assim a jornada do poeta moderno Hipérion em busca da consciência de sua destinação poética, dos percalços, dos erros e dos acertos ao longo 
de sua via excêntrica [exzentrische Bahn], marcada por cisões e desenganos, enfim, por um processo de aproximação infinita de um ideal que se mostra aos poucos inatingível enquanto momento histórico do passado, pertencente à antiguidade grega. Ao mesmo tempo em que toma consciência da distância que separa o moderno do antigo no tempo, Hipérion conscientiza-se das características e das peculiaridades do moderno. No conhecido "Discurso de Atenas", passo fundamental da formação de Hipérion, o antiherói moderno chega finalmente à clara visão de sua tarefa, a recondução da filosofia à sua origem, à poesia, bem como do caráter ideal de uma tarefa que é em si mesma infinita:

- Sem a poesia [...] eles [os atenienses] jamais teriam sido um povo filosófico!

- O que a filosofia [...], o que a superioridade fria dessa ciência tem a ver com a poesia?

- A poesia [...] é o começo e o fim dessa ciência. Ela se origina da poesia de um ser divino infinito, como Minerva da cabeça de Júpiter. E desse modo, afinal, o incompatível conflui novamente para ela, para a fonte misteriosa da poesia. ${ }^{35}$

\section{Poética moderna}

Em seu Ensaio sobre o trágico, Peter Szondi mostrou a mudança de concepção operada na produção de Hölderlin a partir de 1803, quando o poeta se põe a traduzir as tragédias de Sófocles para o alemão ${ }^{36}$ Espécie de viragem para a maturidade, tal mudança se reflete nos hinos tardios, como no Celebração da paz [Friedensfeier], em que a oposição entre natureza e arte, própria da juventude, se transforma na oposição entre humano e divino. As Observações sobre Édipo e Antígona, de 1803, escritas sob forte influência das traduções de Sófocles, são marcadas por essa viragem. Se, antes, os textos teóricofilosóficos de Hölderlin calcavam-se em sua própria produção poética, agora, o centro de sua atenção estético-filosófica se volta para o modelo da poesia antiga de Sófocles. Ao traduzir as tragédias de Édipo e Antígona, Hölderlin toma consciência da importância da mechané inerente à poesia trágica grega, responsável por elevá-la ao patamar sublime alcançado com Sófocles. Inconsciente na alma dos poetas, essa mechané é revelada pela Poética de Aristóteles que, num intenso debate com Platão, recupera a centralidade e a importância da poesia e do poeta para a formação da polis, abalada na República.

O projeto de realização de uma poética filosófica, presente na produção de Hölderlin desde a juventude, alcança seu ápice com as Observações sobre Édipo e Antígona. Nesta obra, Hölderlin efetiva aquilo que havia ficado sempre inacabado e reticente: uma poética tipicamente moderna, capaz de revelar os fundamentos filosóficos da práxis poética moderna, a partir de uma comparação com a mechané antiga, numa exposição ela própria poética e não lógico-discursiva:

A fim de garantir aos poetas, também entre nós, uma existência de cidadão, será bom elevar a poesia, também entre nós, à altura da mechané dos antigos, considerando a diferença das épocas e das constituições. 
Também às outras obras de arte, comparadas às gregas, falta confiabilidade; pelo menos, elas foram até agora julgadas mais pelas impressões que causam do que pelo cálculo de suas leis e outros modos de proceder, por meio dos quais o belo é produzido. À poesia moderna falta particularmente escola e ofício, isto é, que o seu modo de proceder possa ser calculado e ensinado e, quando for aprendido, possa ser repetido de modo confiante em sua execução. ${ }^{37}$

Essa concepção, elaborada em 1803, está ligada à experiência de frustração com a realização da tragédia moderna $A$ morte de Empédocles, que Hölderlin deixou inacabada. Seu "fracasso" deriva da inexistência de uma poética moderna, de um discurso filosófico capaz de revelar e trazer à consciência a mechané interna da poesia moderna. Falta ao poeta moderno justamente a reciprocidade entre a produção poética (a práxis) e o discurso filosófico-racional sobre ela, que ilumine seus mecanismos, sua lógica poética inerente, como a Poética de Aristóteles fez com Sófocles. A morte de Empédocles permaneceu inconclusa porque faltou ao poeta moderno "escola e ofício, isto é, que o seu modo de proceder possa ser calculado e ensinado". Faltou-lhe o amparo de um discurso que revelasse os contornos do elemento propriamente racional da poesia, o qual deve limitar adequadamente o entusiasmo [Begeisterung] do poeta e fornecer-Ihe o arcabouço necessário para seu ato criador. Tal discurso, resumidamente, deve descortinar a "lei calculável", o logos da poesia ${ }^{38}$, que tem por função garantir a comunicabilidade dos poetas ao longo das gerações, e permitir a elevação da poesia moderna à altura da poesia trágica grega.

A lei calculável da poesia grega consiste, grosso modo, na possibilidade de dividir o drama em duas metades desiguais. No caso do Édipo, o ponto de intersecção é situado na fala de Tirésias e, no caso de Antígona, na fala em que a heroína particulariza a lei de Zeus, ao proclamar "o meu Zeus". ${ }^{39}$ Batizado cesura, palavra pura ou interrupção antirrítmica, esse ponto de intersecção do drama é responsável pela mudança dilacerante [reissender Wechse/] dos acontecimentos, a partir da qual o tempo muda, tornando-se propriamente trágico. Ao aparecer em diferentes momentos no Édipo e na Antígona, a cesura torna possível calcular o ritmo de surgimento das representações, a parte posterior mais rápida do que a anterior, de modo que se opera um corte na representação, impedindo-a de se tornar êxtase puro. O corte operado pela cesura no interior da representação garante a sobriedade consciente (filosófica) do que é representado por parte do espectador, pois a cesura, ao instaurar um corte no ritmo das representações, interrompe o fluxo de tonalidades, disposições verbais e percepções poéticas, mantendo claro o limite que permite identificar a representação como representação poética.

Acima de tudo, o fato de ser possível encontrar a lógica poética leva à constatação de que a poesia de modo geral não depende apenas do entusiasmo ou da inspiração divina, mas da relação harmônica e recíproca entre inspiração e técnica. A poesia não é apenas fruto de um ser febril e enlevado, nem do entendimento técnico, que enxerga a poesia 
apenas como cálculo. Hölderlin, nesse ponto, acata recomendação de Schiller, o qual havia Ihe escrito que a maior qualidade do poeta consiste em saber manter "a sobriedade no entusiasmo [die Nüchternheit in der Begeisterung]". ${ }^{40}$ Cinco anos após ter recebido esta carta, Hölderlin utiliza numa carta a Casimir Böhlendorff, de 4 de dezembro de 1801, o termo sobriedade, referindo-se aos gregos. A grandeza desse povo, escreve, estaria no feito de terem conseguido expor o seu elemento natural e inato, nacional (o pathos sagrado, a bela comoção), em seu oposto, na forma sóbria de Juno (ou sobriedade junônica). Por antonomásia, deduz que os modernos, sendo seu elemento natural, inato e nacional a sobriedade de Juno, têm como tarefa poética justamente a busca pelo oposto, o pathos sagrado e a bela comoção na forma, caso desejem atingir o equilíbrio e a harmonia da poesia grega:

Acredito que, para nós, a clareza da exposição é, originariamente, tão natural como foi, para os gregos, o fogo do céu. Por isso também é que os gregos se deixam ultrapassar mais pela bela comoção [...] do que pela presença do espírito homérico e seu dom de exposição [...] [Os gregos] foram [...], desde Homero, exímios quanto ao dom da exposição, pois esse homem extraordinário possuía uma alma suficientemente plena para apresar, em seu reino apolíneo, a sobriedade ocidental de Juno e, assim, apropriar-se verdadeiramente do estranho. Conosco dá-se o inverso. Daí ser tão perigoso abstrair as nossas regras artísticas, única e exclusivamente, da excelência grega. ${ }^{41}$

A excelência do moderno depende da compreensão de que a sua natureza é diametralmente oposta à do grego, o que só pode ser entendido por meio de um estudo profundo da poesia grega. O conhecimento do elemento próprio [das Eigene] do moderno, por outro lado, provém do estudo não apenas da poesia, mas também da filosofia moderna, particularmente de Kant, filósofo com o qual Hölderlin se ocupa desde a juventude, como dito anteriormente. A leitura da estética de Kant (juntamente com o estudo dos gregos) torna-se fundamental nessa busca de uma poética moderna, perseguida por Hölderlin ao longo de todos esses anos de contato com a filosofia. $\mathrm{Na}$ Crítica da faculdade do Juízo, Hölderlin encontra uma primeira tentativa filosófica de fundamentação do métier do poeta moderno ${ }^{42}$, precisamente na relação mútua e interdependente entre criação (natureza) e gosto (cultura) que Kant estabelece em seu conceito de gênio. Embora Kant defina o gênio, por um lado, como um "dom natural" por meio do qual a própria natureza "dá a regra a arte", como um ato radicalmente criador e produtivo, por outro, ele reitera a necessidade das regras do gosto, cuja função é justamente limitar a criação genial, impedindo-a de se tornar exaltação [Schwärmere]]. Apesar de se fundamentar inteiramente na atividade da imaginação produtiva, Kant é explícito ao afirmar que o gênio deve formar e limitar essa criatividade nas regras do gosto. Na passagem conclusiva do $\S 50$ da terceira crítica, afirma:

O gosto é, assim como a faculdade do juízo em geral, a disciplina (ou educação) do gênio; corta-lhe muito as asas e torna-o morejado e polido; ao mesmo tempo, porém, 
dá-Ihe uma direção sobre o que e até onde ele deve estender-se para permanecer conforme a fins; e na medida em que ele introduz clareza e ordem na profusão de pensamentos, torna as ideias consistentes, capazes de uma aprovação duradoura e ao mesmo tempo universal, da sucessão de outros e de uma cultura sempre crescente. ${ }^{43}$

Ao cortar as asas do gênio exaltado, dando-lhe direção e disciplina, a regra do gosto garante a sucessão de gênios originais, cujos espíritos são vivificados pela obra um do outro, sedimentando assim a própria história da arte. Entendido como sensus communis (sentido comunitário), é o gosto, segundo Kant, "que torna o nosso sentimento, numa representação dada, universalmente comunicável, sem a mediação de conceitos". ${ }^{44}$ Nesse sentido de senso comum, o gosto permite que se chegue a um consenso em relação a uma obra de arte específica (como por exemplo o reconhecimento de Homero ou Shakespeare pela história como gênios), mas sem determinar por conceitos. Segundo Kant, é preciso que, na delimitação do gosto pela regra, a liberdade seja preservada, condição sem a qual o produto do gênio carecerá de originalidade:

De acordo com estes pressupostos, o gênio é a originalidade exemplar do dom natural de um sujeito no uso livre das suas faculdades de conhecimento. Deste modo o produto de um gênio [...] é um exemplo não para a imitação [...], mas para a sucessão por outro gênio, que por este meio é despertado para o sentimento da sua própria originalidade, exercitando na arte uma tal liberdade em relação à coerção de regras, que a própria arte obtém por este meio uma nova regra, pela qual o talento se mostra como exemplar. ${ }^{45}$

$\mathrm{Na}$ abertura das Observações sobre Édipo, Hölderlin dirá que, carente de escola e ofício, o problema da poesia moderna é precisamente que ela não pode ser calculada e ensinada. Ao criar, cada um dos poetas modernos precisa recomeçar sempre do zero, reinventando eternamente os princípios sobre os quais a poesia como um todo deve se basear. Tomar consciência das peculiaridades da poesia moderna corresponde a tomar consciência da forma como o poeta moderno utilizará o que é propriamente moderno. $\mathrm{Na}$ carta acima citada a Böhlendorff, Hölderlin definirá a tarefa suprema designada ao poeta moderno como "o livre uso do próprio" ou nacional. Considerado o mais difícil de ser alcançado, esse livre uso do próprio ou nacional consiste em saber reconhecer, por um lado, o que é natural de um povo, ou nacional, e, por outro, saber expô-lo livremente em seu oposto, isto é, sem ser constrangido pela regra que, no entanto, é também pressuposta na criação. "Nada é mais difícil de aprender do que o livre uso do nacional" ${ }^{\prime 6}$, afirma, deixando claro que a poética moderna, que ele procurava estabelecer, traria em si um paradoxo: saber tornar-se outro sem abrir mão de si mesmo. Em última análise, tal preceito valeria também para a relação entre filosofia e poesia de modo geral.

No rico material destinado a ser publicado na revista Iduna, as assim chamadas Reflexões, Hölderlin refaz da seguinte forma o preceito poético de Kant para os modernos: 
A medida do entusiasmo dada a todo indivíduo singular deve ser tal que, a um com ardor mais vivo, a outro com um ardor mais tênue, possa-se conservar a consciência na medida necessária. O momento em que a sobriedade te abandona, este é o limite de teu entusiasmo. ${ }^{47}$

Acima de tudo, afirmações como esta deveriam ser suficientes para relativizar a imagem errônea que se formou de Hölderlin ao longo da história como um poeta etéreo e seráfico, para quem a filosofia constituiu apenas mais uma de suas aventuras inconsequentes. Longe disso, a relação com a filosofia se mostra imprescindível para a poesia moderna, em sua busca pela tão necessária poética, sem a qual ela tenderia a desaparecer por completo, tal como, posteriormente, veio corroborar a tese do fim da arte de Hegel.

\section{* Ulisses Vaccari é professor do Departamento de Filosofia da UFSC.}

1 Cf. HELlingRATH, N. V. Hölderlin, Sämtliche Werke, Historisch-kritische Ausgabe, MunichLeipzig, 1913.

2 Os três hinos foram traduzidos por Paulo Quintela em Poemas. Coimbra: Atlântida, 1959. Friedensfeier, considerado o hino mais significativo de Hölderlin, só foi descoberto em 1954.

${ }^{3}$ Cf. DILTHEY, W. Das Erlebnis und die Dichtung. Lessing, Goethe, Novalis, Hölderlin. Göttingen: Vandenhoeck \& Ruprecht, 1921.

${ }^{4}$ Cf. BENJAMIN, W. "Zwei Gedichte von Friedrich Hölderlin". In: Gesammelte Schriften II, 1, Frankfurt, 1977, pp. 105-126. Cf. a tradução brasileira de Susana Kampf Lages e Ernani Chaves. In: Escritos sobre mito e linguagem (1915-1921). São Paulo: Editora 34, 2011.

${ }^{5}$ Cf. CASSIRER, E. "Hölderlin und der deutsche Idealismus". In: Idee und Gestalt. Darmstadt: Wissenschaftliche Buchgesellschaft, 1975.

${ }^{6}$ Cf. HEIDEGGER, M. "Erläuterungen zu Hölderlins Dichtung”. In: Gesammtausgabe 4, Franfkfurt am Main: Vittorio Klostermann Verlag, 2012; Explicações da poesia de Hölderlin. Tradução de Cláudia Drucker. Brasília: Ed. UnB, 2013.

${ }^{7}$ Cf. ADORNO, T|. W. "Parataxis. Zur späten Lyrik Hölderlins”. In: Noten zur Literatur. Gesammelte Schriften, 11, Franfurt am Main: Suhrkamp, 2003, pp. 447 - 491.

8 O fragmento havia sido descoberto por Cristoph Theodor Schwab, o primeiro biógrafo de Hölderlin, que o vendeu em um leilão à biblioteca Schocken, em Jerusalém. Em 1970, a Württenbergische Landesbibliothek arrematou-o em outro leilão, fazendo com que o fragmento retornasse à Alemanha. Para a história do fragmento, cf. HENRICH, D. Der Grund im Bewusstsein. Untersuchungen zu Hölderlins Denken (1794-1795). Stuttgart: Klett-Cotta, 1992, p. 29; e BECKEMKAMP, J. Entre Kant e Hegel. Porto Alegre: EDIPUCRS, 2004, pp. 101-133.

${ }^{9}$ Segundo Hegel, numa carta a Schelling, de 16 de abril de 1795: "Hölderlin me escreve às vezes de lena. Ele ouve Fichte e fala dele com entusiasmo como um titã que lutaria pela humanidade" (Briefe von und an Hegel. Edição organizada por J. Hoffmeister. Hamburg: Felix Meiner Verlag, 1952, p. 18). Numa carta anterior, com efeito, de 26 de janeiro de 1795, Hölderlin havia mostrado a Hegel o quão imerso estava nos estudos da filosofia de Fichte, tendo lido, ao mesmo tempo em que frequentava seus cursos, a versão impressa da Grundlage e das Preleções sobre o destino do erudito: "As páginas especulativas de Fichte - Fundação a toda doutrina-da-ciência - e também suas preleções impressas sobre o Destino do Erudito muito te interessarão" (HÖLDERLIN, F. Sämtliche Werke III. Frankfurt am Main: Deutscher Klassiker Verlag, 1992, p. 176; doravante: SW). 
Cf. VACCARI, U. R. "O titã de lena: a recepção de Fichte por Hölderlin". In: Revista de Filosofia Aurora, v. 27, n. 42, pp. 859-872.

10 Diferentemente do período de Frankfurt (1796-1798), em que dominava a ode na produção poética de Hölderlin, a partir de 1800 a elegia passa a constituir o traço mais marcante de sua criação. É comum afirmar (cf. SCHMIDT, J. SW I, p. 495 e ss.) que essa virada coincide com o rompimento da relação amorosa com Susette Gontard, a quem o poeta havia dedicado o Hipérion. Coincide com esse rompimento, além disso, uma série de odes e elegias dedicadas à terra natal (Der Neckar, Heidelberg, Rückehr in die Heimat, Studgart, Der Wanderer), sugerindo o sentimento crescente de estranheza em relação à sua existência de poeta diante do mundo real. A figura da pátria, da terra natal, torna-se um ideal a ser buscado poeticamente, por meio da imaginação, da recordação e da história, e é essa busca que caracteriza a forma elegíaca, dominante na produção de Hölderlin de 1801 a 1806.

${ }^{11}$ É nesse sentido que Heidegger define Hölderlin como o poeta dos poetas: "À essência do poeta que, em tal tempo do mundo, é verdadeiramente poeta, pertence o fato de, para ele, de antemão e a partir da indigência do mundo, o poetar e a vocação poética se tornarem questões poéticas. Por isso, os 'poetas em tempo indigente' têm que poetar a própria essência da poesia" ("Para quê poetas?". In: Caminhos de Floresta. Tradução de Irene Borges Duarte, Filipa Pedroso, Alexandre Franco de Sá, Hélder Lourenço, Bernhard Silva, Vítor Moura e João Constâncio. Lisboa: Calouste Gulbenkian, 2014, pp. 312-313).

12 HÖLDERLIN, F. Poemas. Tradução de Paulo Quintela. Coimbra: Atlântida, 1959, p. 219.

${ }^{13}$ Hipérion ou o eremita na Grécia. Tradução de Erlon José Paschoal. São Paulo: Nova Alexandria, 2003, p. 87.

${ }^{14}$ SCHILLER, F. Cartas sobre a educação estética do homem. Tradução de Márcio Suzuki. São Paulo: lluminuras, 1990, p. 43.

15 Ibidem, p. 14.

16 Ibidem, p. 87.

${ }^{17}$ Ibidem, p.97, nota. Os três passos da história da humanidade aparecem também em Poesia ingênua e sentimental: "Este caminho que os poetas modernos seguem é, de resto, o mesmo que o homem em geral tem de trilhar, tanto individualmente quanto no todo. A natureza o faz uno consigo; a arte o cinde e desune; pelo Ideal, ele retorna à unidade" (Tradução de Márcio Suzuki. São Paulo: lluminuras, 1991, p. 61).

${ }^{18}$ Hipérion. Op. cit., p. 67, grifo meu.

${ }^{19}$ Cf. KANT, I. Crítica da razão pura. Tradução de Fernando Costa Mattos. São Paulo: Vozes, 2012, pp. 290-300 (B 378-396).

${ }^{20}$ Cf. Idem. Crítica da faculdade do Juízo. Tradução de António Marques e Valério Rohden. Lisboa: Calouste Gulbenkian, 1998, p. 219 (B 192).

${ }^{21}$ Ibidem, p.220 (B 194).

22 "Talvez eu possa te enviar um texto sobre as ideias estéticas, pois ele pode valer como comentário sobre o Fedro de Platão [...]. No fundamental, ele deve conter uma análise sobre o belo e o sublime, que simplifica a análise kantiana e, por outro lado, a vê de múltiplas formas, como Schiller fez em parte em seu escrito Sobre graça e dignidade, embora não tenha dado um passo para além do limite kantiano, como, em minha opinião, ele deveria ter ousado" (SW III, p. 157).

${ }^{23}$ Das älteste Systemprogramm des deutschen Idealismus. In: SW II, p. 576.

${ }^{24}$ A crítica ao princípio da identidade como forma de recuperação do Ser perdido aparece, por exemplo, em Juízo e ser, na afirmação segundo a qual "esse Ser não deve ser confundido com a identidade" (SW II, p. 502), em clara referência ao primeiro princípio pura e simplesmente 
incondicionado da filosofia de Fichte, a saber, "eu sou eu", fundada no princípio A = A. Cf. FICHTE, J. G. A doutrina da ciência de 1794. Coleção Os pensadores. São Paulo: Abril, pp. 43-49.

${ }^{25}$ Cartas sobre a educação estética do homem. Op. cit., p. 100. Essa ideia em particular, assim como outras que aparecem nas Cartas de Schiller, constitui um dos passos essenciais da Doutrina da ciência de Fichte, conhecido como o método da determinação recíproca entre eu e não-eu, que inaugura o pensamento propriamente dialético-especulativo, e que Schiller toma emprestado de Fichte, que assim a define: "Pela determinação em geral é meramente fixada quantidade; sem se investigar como e de que maneira; pelo conceito sintético que acabamos de estabelecer é posta a quantidade de um pela de seu oposto e vice-versa. Pela determinação da realidade ou negação do eu é ao mesmo tempo determinada a negação ou realidade do não-eu; e vice-versa. Posso partir de qual dos opostos quiser, e de cada vez, por uma ação de determinar, terei determinado, ao mesmo tempo, o outro. Essa determinação mais determinada poder-se-ia legitimamente denominar determinação recíproca (por analogia com ação recíproca). É o mesmo que, em Kant, se chama relação" ( $A$ doutrina-da-ciência de 1794. Op. cit., p. 67). O método da determinação recíproca, criado por Fichte, em curtas palavras, consiste em que, ao determinar um conceito, por exemplo, o Eu, seu oposto deva também sofrer determinação, o não-Eu, de modo que a negação de um resulte na realidade do outro. Nas palavras de Schiller: "É somente através de limites, portanto, que chegamos à realidade; somente pela negação ou exclusão chegamos à posição ou postulação real; somente pela supressão de nossa livre determinabilidade à determinação" (Cartas sobre a educação estética do homem. Op. cit., p. 100).

26 "Anmerkungen zum Oedipus". In: SW II, p. 856. Cf. Observações sobre Édipo e Antígona. Tradução de Pedro Süssekind. Rio de Janeiro: Jorge Zahar, 2008, p .78. Além do Juízo e ser, o tema aparecia também no Prefácio à penúltima versão de Hipérion: "A bem-aventurada unicidade, o Ser, no único sentido da palavra, está perdido para nós, e precisávamos perdê-lo se devemos esforçar-nos por ele, conquistá-lo. Arrancamo-nos do pacífico En Kai Pan do mundo para produzilo por nós mesmos" (In: SW II, p. 256).

${ }^{27}$ Nesse sentido, concorda-se com a tese de Peter Szondi segundo a qual a filosofia do trágico do idealismo alemão procura pensar a Ideia filosófica por trás do gênero trágico, a qual se baseia na concepção de dialética (ou paradoxo), em oposição à concepção de gêneros do discurso poético da tradição das poéticas da tragédia. Cf. Ensaio sobre o trágico. Tradução de Pedro Süssekind. Rio de Janeiro: Jorge Zahar, 2004, pp. 23-25. Ao determinar o conceito de dialética, porém, Szondi permanece ligado à sua acepção hegeliana, ignorando a origem fichtiana do conceito de determinação recíproca como fundamento do trágico em Hölderlin. Ao analisar o fragmento 0 significado das tragédias, em que Hölderlin menciona o paradoxo, Szondi (cf. pp. 33-36) não menciona o conceito de determinação recíproca, antes atribuindo a ele uma dialética histórica entre fidelidade e infidelidade. Que o conceito de Fichte seja de extrema importância a Hölderlin e não possa ser ignorado em seu projeto estético, deduz-se, por exemplo, da carta a Hegel de 26 de janeiro de 1796, em que sentencia: "Sua discussão [de Fichte] sobre a ação recíproca do eu e do não-eu (para falar como ele) é de fato digna de nota; assim como a ideia de aspiração etc." (SW III, p.176). O conceito, de resto, constitui o centro dos ensaios $O$ modo de proceder do espírito poético, Alternância de tons e A diferença dos modos poéticos, todos do ano 1800.

${ }^{28}$ In: Poemas. Op. cit., p. 363.

29 “Die Bedeutung der Tragödien”. In: SW II, p. 561.

${ }^{30}$ In: Poemas. Op. cit., p. 215.

31 “Die Bedeutung der Tragödien". Op. cit., p. 561.

${ }^{32}$ Carta a Schiller de 4 de setembro de 1795. In: HÖLDERLIN, F. Reflexões. Tradução de Márcia C. de Sá Cavalcante e António Abranches. Rio de Janeiro: Relume Dumará, 1994, pp. 111-112.

${ }^{33}$ Hölderlin, nesse sentido, aproxima-se da filosofia do primeiro romantismo de lena, na medida em que estipula, tal como este, a dissolução das formas (gêneros) das poesias individuais no 
movimento de aproximação infinita do absoluto da Arte. No caso do romantismo de lena, é imprescindível a concepção de Poesia Universal Progressiva, tal como fundamentada no fragmento 116 do Pólen: "A poesia romântica é uma poesia universal progressiva. Sua destinação não é apenas reunificar todos os gêneros separados da poesia e pôr a poesia em contato com a filosofia e retórica. Quer e também deve ora mesclar, ora fundir poesia e prosa, genialidade e crítica, poesia-de-arte e poesia-de-natureza..." (SCHLEGEL, F. O dialeto dos fragmentos. Tradução de Márcio Suzuki. São Paulo: Iluminuras, 1997, p. 64). A aproximação entre Hölderlin e os românticos de lena no que se refere à fundição entre poesia e prosa é realizada por Walter Benjamin. Cf. O conceito de crítica de arte no romantismo alemão. Tradução de Marcio SeligmannSilva. São Paulo: lluminuras, p. 108.

${ }^{34}$ Carta a Niethammer de 1796. In: Reflexões. Op. cit., p. 113 (tradução modificada).

${ }^{35}$ Hipérion. Op. cit, p. 85.

${ }^{36}$ Cf. Ensaio sobre o trágico. Op. cit., p. 35.

37 "Anmerkungen zum Oedipus". SW II, p. 849; trad. brasileira, p. 67.

${ }^{38}$ A lei calculável a que se refere Hölderlin nas Observações tem como modelo a Poética de Aristóteles, que traçou e mapeou as leis internas das peças de Sófocles, trazendo à tona a calculabilidade da práxis poética que tem por finalidade a catarse. Essa calculabilidade da poesia trágica se refere ao mapeamento e ao funcionamento próprio dos conceitos de peripécia (peripeteia), reconhecimento (anagnóresis) e catástrofe (pathos), bem como das seis partes das quais se constitui uma tragédia (mito, caractere, elocução, pensamento, espetáculo e música). Por outro lado, a expressão "logos da poesia" remete de algum modo à expressão "logos da sensibilidade", da Estética de Baumgarten, cujo projeto consistia precisamente na determinação de uma gnosiologia inferior, ou seja, no mapeamento das leis próprias da sensibilidade, em analogia com as leis próprias da razão, o analogon rationis.

39 “Anmerkungen zur Antigonä". SW II, p. 913; trad. brasileira, op. cit., p. 83.

${ }^{40}$ Carta de 24 de novembro de 1796. In: SW III, p. 531.

${ }^{41}$ In: Reflexões. Op. cit., p. 132.

${ }^{42}$ Escreve Kant: "Entre todas as artes, a poesia (que deve sua origem quase totalmente ao gênio e é a que menos quer ser guiada por prescrição ou exemplos) ocupa a posição mais alta" (Crítica da faculdade do Juízo. Op. cit., p. 233; B 215).

${ }^{43}$ Ibidem, p. 226; B 203.

${ }^{44}$ Ibidem, p. 198; B 160.

45 Ibidem, p. 224; B 200.

${ }^{46}$ In: Reflexões. Op. cit., p. 132.

${ }^{47}$ Reflexionen. SW II, p. 519. 